\title{
Isolation and Screening of Antifungal Producing Lactic Acid Bacteria From Pro-Vitamin A Cassava
}

\author{
Bamigbade, G. B. ${ }^{*} \quad$ Omemu, A. M. ${ }^{2} \quad$ Oluwafemi, $\mathrm{F}^{1} \quad$ Obadina, A. O. ${ }^{3}$ \\ 1.Department of Microbiology, Federal University of Agriculture, Abeokuta, Nigeria \\ 2.Department of Hospitality and Tourism, Federal University of Agriculture, Abeokuta, Nigeria \\ 3.Department of Food Science and Technology, Federal University of Agriculture, Abeokuta, Nigeria
}

\begin{abstract}
Lactic Acid Bacteria (LAB) are non-pathogenic bacteria reported to play essential role in preservation, fermentation and contribute to organoleptic and textural profile of food items. This study investigated antifungal producing LAB during fermentation of Pro-vitamin A and white cassava variety which were used against spoilage mould of cassava products (garri, lafun and fufu). One white cassava variety (IITA TMS IBA 30572 (ITI3)) and one yellow variety (IITA TMS IBA 011368 (ITI0)) were fermented for 96 hours. The pH and Total Titratable Acidity (TTA) of the fermenting medium and LAB counts of the supernatant and cassava mash were determined using standard procedures. The LAB were screened with Aspergillus niger to detect their antifungal ability. The LAB were identified as different species which are Lactobacillus plantarum, Lactobacillus fermentum, Lactobacillus mesenteroides, Lactobacillus casei and Lactobacillus acidophilus. These LAB isolates posses the potential to inhibit most of the isolated moulds used in this study. Quantities of lactic acid, diacetyl and hydrogen peroxide produced by the LAB were also determined using standard procedures. It was also observed that the $\mathrm{pH}$ and temperature of the growth medium have significant effect on the production of these antifungal metabolites by the isolated lactic acid bacteria. The proliferation of $\mathrm{LAB}$ at low $\mathrm{pH}$ and their inhibition against some moulds indicate their potential as bio-protective agents in cassava food products.
\end{abstract}

Keywords: Fufu, Lafun, Garri, Fermentation, LAB, Antifungal compounds

DOI: $10.7176 / \mathrm{JNSR} / 9-19-01$

Publication date:October $31^{\text {st }} 2019$

\section{INTRODUCTION}

Cassava (Manihot esculenta Crantz) is an important root crop often processed into various food products in tropical countries. In West Africa the most widely known cassava derived food is garri. Several research works have been carried out on the processing, nutritional and microbiological characteristics and quality improvement of garri (Ogiehor and Ikenebomeh, 2006; Kostinek et al., 2005; Padonou et al.2009). Cassava significantly contributes to food security, incomes and employment opportunities in the rural areas of sub-Saharan Africa (Githunguri et al., 2007). About $38 \%$ of the cassava produced in the coastal lowlands of Kenya is consumed at household level, and $51 \%$ of the farmers make dried chips for domestic use, sale to starch and feed factories or as an intermediate for production of flour (Kiura et al., 2005; Gaheru et al., 2016). As at date, new cassava varieties are being introduced to farmers for their agronomic benefits with little considerations for the quality of the end products.

Today, biofortification provides one of the best ways to achieve improvements in nutrition. Crop breeders at the National Root Crops Research Institute, Umudike in collaboration with the International Institute of Tropical Agriculture, and the Harvest Plus, have worked assiduously to develop cassava varieties that serve as sources of vitamin which led to the development of yellow fleshed cassava roots that have appreciable quantity of pro-vitamin A or carotenes (through bio-fortification) (Akinwunmi, 2011). Vitamin A deficiency is a major public health issue and of global concern. According to the World Health Organization report (WHO, 2002; Olapade and Ogunade, 2014). The pro-vitamin A rich yellow cassava varieties are proposed to be used as a tool in combating vitamin A deficiency (VAD) syndrome especially amongst malnourished women and children in resource poor homesteads. Reduction in the carotenoid contents during processing of yellow root cassava into some food forms has been reported (Bai et al, 2010; Sagar et al., 2009; Omodamiro et al., 2011).

Microbial deterioration and unfavorable biochemical changes of cassava roots are caused by physiological reactions and activities of microorganisms, which enter cassava roots through bruises and cuts caused during harvesting. Traditional processing of cassava chips and flour is generally unhygienic. The chips are sun-dried in open surfaces such as on flat rocks, roads, flat rooftops, flat baskets, or bare ground (FAO, 2005). Storage conditions after drying may also be of high humidity, thus leading to an increase in moisture levels hence creating conducive environments for growth and proliferation of microorganisms. Unhygienic conditions during production (for instance lack of protective clothing, lack of hand washing areas, drying on dirty surfaces), storage and slow sun-drying especially during the rainy seasons, often results in bacteria and mould contamination (Chiona et al., 2014), with for instance Aspergillus species that produce aflatoxins which are a major health concern to humans and livestock (Manjula et al., 2009; Gacheru et al., 2016). Several millions of people in the African continent consume garri and it forms a significant part of the people s diet especially in the West African sub 
region (Edem et al., 2001; Ogiehor et al., 2007; Kostinek et al., 2005 and Oranusi et al., 2014).

A group of bacterial called lactic acid bacteria (LAB), a component of several spontaneously fermented foods including dairy products have long been consumed by humans. Lactic acid bacteria are the focus of intensive research for their essential role in most fermented foods. Representatives of this group of bacteria include Lactobacillus and Bifidobacterium. Lactic acid bacteria (LAB) are the most prominent non-pathogenic bacteria that play a prominent role in our everyday life such as fermentation, preservation and production of wholesome foods and vitamins to prevent certain diseases and cancer due to their antimicrobial action (Saranya et al., 2011). Lactic acid bacteria are the biological basis for the production of a great multitude of fermented foods (Lasagno et al., 2002).

Lactic acid bacteria (LAB) have been exploited for centuries in food fermentations, preservation and are also source of promoting good human health (Oloyede and Afolabi, 2013). First sign of LAB instrumentation date back to $6,000 \mathrm{BC}$, describing the fermentation of milk, fermentation of meat $(1,500 \mathrm{BC})$ and vegetable products $(300$ BC) (Bhattacharyya, 2009). LAB have been widely used as starter cultures for the manufacturing of various fermented foods such as dairies, alcoholic beverages, meat and vegetables etc (Harun-ur-Rashid et al., 2009; Antara et al., 2009). They play important role in food fermentation, primarily by causing the characteristic flavor changes and contributing a preservative effect on the fermented product. Some species of LAB have been used on industrial scale as starter cultures and also as probiotics. Nowadays, LAB and their food products are brought to confer a variety of important nutritional and therapeutic benefits on humans and animals (Boaventura et al., 2012).

Reservative efforts to find microorganisms which produce antibiotic against wide range of pathogens have been pointed out to lactic acid bacteria. The fermented food is a source of various bacteria especially lactic acid bacteria (Anto et al., 2005). The problem of selection of resistant microorganisms to antimicrobials and the increasing demand for safe foods, with less chemical additives, has increased the interest in replacing these compounds by natural products, which do not injure the host or the environment (Kapil, 2005). Biotechnology in the food-processing sector targets the selection, production and improvement of useful microorganisms and their products as well as their technical application in food. Foods that have been processed could be spoilt during storage in certain period of time, even though they have been designated free from harmful microorganisms. This condition has pushed food producers to frequently use high dose of dangerous chemical preservative in order to extend the shelf life of the products. (Anto et al., 2005).

Fungi have a profound biological and economic impact as food spoilage agents, decomposers, plant and animal pathogens (Oranusi et al., 2013). Moulds and yeasts are common spoilage microorganisms of food products and are responsible of 5 to $10 \%$ of world's food lost (Schnurer and Magnusson 2005). A few studies have reported the antifungal activity of some lactic acid bacteria (LAB) through the production of phenyllactic acid (Lavermicocca et al., 2003), cyclic dipeptides, 3-hydroxy fatty acids and peptides (Storm et al., 2002; Sjogren et al., 2003). The inhibition of growth of spoilage organisms may also be due to the production of many metabolites such as organic acids (lactic and acetic acid), hydrogen peroxide, diacetyl and bacteriocins (Ennahar et al., 2000). The incorporation of these compounds as biopreservative ingredient into model food has been shown to be effective in the control of pathogenic and spoilage microorganisms (Mc Auliffe et al., 2001). For this reason, LAB have received much attention for use as natural or biopreservatives in food in recent years (Savadogo et al., 2004). Therefore, the study is aimed at isolating and characterizing antifungal producing LAB present in fermenting provitamin A and assessing the activity of the antifungal metabolites produced against spoilage moulds of cassava products by these bacteria.

\section{MATERIALS AND METHODS}

\subsection{Collection of samples}

Samples were collected randomly from cassava root and cassava products. Fresh roots $(5 \mathrm{~kg}$ each) of white root variety; IITA TMS IBA 30572 and yellow root variety; IITA TMS IBA 011368 were obtained in a clean sack from International Institute of Tropical Agriculture (IITA), Ibadan, Oyo state, Nigeria and brought to the Postgraduate Laboratory, Microbiology Department, Federal University of Agriculture, Abeokuta, Ogun State, Nigeria. Three different cassava products namely: "Fufu", "Lafun" and "Garri" were produced in the laboratory from the obtained cassava roots. The cassava effluent was obtained from fermentation of the cassava root in the laboratory.

\subsection{Samples Preparation}

Pro-vitamin A and white cassava were fermented using the submerged fermentation technique. Five hundred grams $(500 \mathrm{~g})$ of the three varieties of the cassava were separately peeled, cut in to smaller sizes, washed and soaked in an air tight container with $1500 \mathrm{ml}$ of water and fermented for 96hours at room temeperature $\left(28 \pm 2^{\circ} \mathrm{C}\right)$. The fermentation supernatant and mash samples were collected at $12 \mathrm{hrs}$ interval for microbiological analysis. "Fufu", "Lafun" and "Garri" were produced in the laboratory from the obtained cassava roots. About $1.5 \mathrm{~kg}$ each of the cassava root varieties were used for the production of the three cassava products. Roots of each variety were 
separately peeled, cut into small sizes and washed. The products were all produced using traditional methods.

\subsection{Determination of $\mathbf{p H}$}

The $\mathrm{pH}$ change of the fermenting medium was monitored at 12 hours intervals using a $\mathrm{pH}$ meter. The method described by Wakil and Osamwonyi (2012) was used. Ten milliliters of the fermenting gruel was aseptically removed from the fermenting medium and its $\mathrm{pH}$ was determined with the aid of a pre-standardized $\mathrm{pH}$ meter (HANNA instrument) by inserting the $\mathrm{pH}$ electrode inside the samples and taking the reading on the monitor.

\subsection{Titratable acidity}

The procedure described by Wakil and Osamwonyi (2012) was used. The titratable acidity (expressed as percentage lactic acid) was determined by shaking the fermenting vessel to enable mixing of fermentation water and fermenting cassava. The samples were collected at 12 hours interval. Twenty five milliliters $(25 \mathrm{ml})$ of the fermentation supernatant from the two varieties of cassava were collected separately in different conical flasks and labeled accordingly. The collected fermentation supernatant was titrated against $0.1 \mathrm{M} \mathrm{NaOH}$ using $1 \mathrm{ml}$ of phenolphthalein as indicator. The total titratable acidity was calculated as lactic acid $(\% \mathrm{w} / \mathrm{v})$.Each milliliter of 1 $\mathrm{N} \mathrm{NaOH}$ is equivalent to $90.08 \mathrm{mg}$ of lactic acid. The total titratable acidity was then calculated as stated in A.O.A.C (2000).

\subsection{Isolation and characterization of Lactic Acid Bacteria}

Lactic acid bacteria were isolated from the fermentation supernantant and cassava mash generated from the fermentation of the two varieties of cassava roots. One milliliters of the fermentation supernatant and $1 \mathrm{~g}$ of the mash were aseptically removed from the fermenting vessels for serial dilution at 12 hours and plated out on De Mann Rogosa and sharpe (MRS) agar at $37^{\circ} \mathrm{C}$ for 48 hours.. Pure cultures were maintained on MRS agar slants and stored at $4^{\circ} \mathrm{C}$ for further studies. The LAB isolates were characterized phenotypically and were identified using Bergey's Manual of Determinative Bacteriology (Wakil and Osamwonyi, 2012). Further characterization was carried out using molecualar methods.

\subsection{Screening of lactic acid bacteria for antifungal activity}

The LAB isolates were assayed for antifungal activity using modified overlay method described by Rouse et al., 2008 as an initial screening step. On MRS agar plates, LAB after growing at $30^{\circ} \mathrm{C}$ overnight in MRS broth were streaked. The plates were allowed to grow anaerobically at $37^{\circ} \mathrm{C}$ for $48 \mathrm{hrs}$. The plates were then overlaid with PDA that contained mould spores per $\mathrm{ml}$ of indicating organism. After $24-48 \mathrm{hrs}$ of aerobic incubation at $28^{\circ} \mathrm{C}$, inhibition zone around the LAB were measured. The inhibition was graded according to the size of inhibited growth area. Inhibition test was performed in triplicate. The degree of inhibition was calculated as area of inhibited growth in relation to the total area of the Petri dish and the scale was the following: - = no visible inhibition, $+=$ no fungal growth on $0.1-3 \%$ of plate area, $++=$ no fungal growth on $3-8 \%$ of plate area, $+++=$ no fungal growth on $>8 \%$ of plate area.

\subsection{Production of Metabolites by the Lactic acid bacteria}

The antifungal producing isolates with inhibition greater than $8 \%$ were cultivated in MRS broth and incubated anaerobically for $24 \mathrm{hrs}$ at $30^{\circ} \mathrm{C}$. The broth culture was centrifuged at $5000 \mathrm{rpm}$ for $15 \mathrm{mins}$ and cell-free supernatants (CFS) (filtrate) were used as inoculums (Wakil and Osamwonyi, 2012).

\subsection{Detection of antifungal activity by agar well diffusion method}

Antifungal assay was performed by using the agar well diffusion method. Potato Dextrose Agar medium seeded with each test mould strains was added the added to sterile Petri dishes. The plates were allowed to dry and a sterile cock borer of diameter $5.00 \mathrm{~mm}$ was used to dig wells of equal distance seeded plates. Before the assays, the isolated LAB strains were twice pre-cultured in MRS broth, for $24 \mathrm{hrs}$ at $37^{\circ} \mathrm{C}$. Afterwards, each well was filled with $50 \mu \mathrm{l}$ of each CFS and one well was filled with sterile distilled water to serve as a negative control. All the assays were carried out in triplicates (for each spoilage moulds). The plates were left for sometimes to allow the test materials to diffuse in the agar and then incubated at $37^{\circ} \mathrm{C}$ for $48 \mathrm{hrs}$. The antifungal activity was assayed by measuring the diameter of the clear zone of inhibition formed around the well. The diameter $(\mathrm{mm})$ of the zone of inhibition of $1.5 \mathrm{~mm}$ and above was considered as a significant inhibition (Muhialdin, 2013)

\subsection{Production of Antifungal Metabolites by Lactic Acid Bacteria}

2.9.1.Quantitative Estimation of Lactic Acid: The quantity of lactic acid produced by bacteria isolates was carried out using the method described by Wakil and Osamwonyi (2012). The quantity of lactic acid produced by antimicrobial producing isolates at $24 \mathrm{hrs}, 48 \mathrm{hrs}, 72 \mathrm{hrs}$ and $96 \mathrm{hrs}$ was determined by transferring $25 \mathrm{ml}$ of broth cultures of test organisms into $100 \mathrm{ml}$ flasks. This was titrated with $0.1 \mathrm{M} \mathrm{NaOH}$ and $1 \mathrm{ml}$ of phenolphthalein 
indicator. The titratable acidity was calculated as lactic acid (\% w/v). Each milliliter of $1 \mathrm{M} \mathrm{NaOH}$ is equivalent to $90.08 \mathrm{mg}$ of lactic acid. The titratable acidity was then calculated as stated in A.O.A.C (2000).

Lactic acid produced $=\underline{\mathrm{ml} \mathrm{NaOH} \times \mathrm{M} \mathrm{NaOH} \times \mathrm{M}}$.E $\times 100$

Where;

\section{Weight of sample}

$\mathrm{ml} \mathrm{NaOH}=$ volume of $\mathrm{NaOH}$ used

$\mathrm{M} \mathrm{NaOH}=$ molarity of $\mathrm{NaOH}$

$\mathrm{M} . \mathrm{E}=$ equivalence factor $(90.08 / \mathrm{mg})$

2.9.2. Quantitative Estimation of Diacetyl: The quantity of diacetyl produced by bacteria isolates was carried out using the method described by Wakil and Osamwonyi (2012). Diacetyl production at $24 \mathrm{hrs,} 48 \mathrm{hrs}, 72 \mathrm{hrs}$ and 96 hrs was determined by transferring $25 \mathrm{ml}$ of broth cultures of test organisms into $100 \mathrm{ml}$ flasks. Hydroxylamine solution $(7.5 \mathrm{ml})$ of 1 molar was added to the flask and to a similar flask for residual titration. Both flasks were titrated with $0.1 \mathrm{M} \mathrm{HCl}$ to a greenish yellow end point using bromothymol blue as indicator. The equivalence factor of $\mathrm{HCl}$ to diacetyl is $21.52 \mathrm{mg}$. The concentration of diacetyl produced was calculated using the A.O.A.C. (2000).

$\mathrm{AK}=\frac{(\mathrm{b}-\mathrm{s})(100 \mathrm{E})}{\mathrm{W}}$

Where;

$\mathrm{Ak}=\%$ of diacetyl

$\mathrm{b}-\mathrm{s}=$ volume of $\mathrm{HCl}$ used

$\mathrm{E}=$ equivalence factor $(21.52 / \mathrm{mg})$

$\mathrm{W}=$ volume of broth

$100=$ constant

2.9.3.Quantitative Estimation of Hydrogen Peroxide: The quantity of hydrogen peroxide produced by bacteria isolates was carried out using the method described by Wakil and Osamwonyi (2012). Hydrogen peroxide production at $24 \mathrm{hrs}, 48 \mathrm{hrs}, 72 \mathrm{hrs}$ and $96 \mathrm{hrs}$ was determined by measuring $25 \mathrm{ml}$ of broth cultures of the test organisms into a $100 \mathrm{ml}$ flask. To this was added $25 \mathrm{ml}$ of freshly prepared $0.1 \mathrm{M} \mathrm{H}_{2} \mathrm{SO}_{4}$. This was then titrated with $0.1 \mathrm{M}$ potassium permanganate $\left(\mathrm{KMnO}_{4}\right)$. Each milliliter of $0.1 \mathrm{~N} \mathrm{KMnO}_{4}$ is equivalent to $1.701 \mathrm{mg}^{\circ} \mathrm{H}_{2} \mathrm{O}_{2}$. A decolorization of the sample was regarded as the end point. The volume of $\mathrm{H}_{2} \mathrm{O}_{2}$ produced was then calculated (A.O.A.C; 2000).

$\mathrm{H}_{2} \mathrm{O}_{2}$ produced $=\underline{\mathrm{ml} \mathrm{KMnO}_{4}} \times \mathrm{NKMnO}_{4} \times$ M.E $\times 100$

Where; $\mathrm{ml} \mathrm{H}_{2} \mathrm{SO}_{4} \mathrm{x}$ Volume of sample used

$\mathrm{ml} \mathrm{KMnO}_{4}=$ volume of $\mathrm{KMnO}_{4}$

$\mathrm{N} \mathrm{KMnO}_{4}=$ Normality of $\mathrm{KMnO}_{4}$

$\mathrm{ml} \mathrm{H}_{2} \mathrm{SO}_{4}=$ Volume of $\mathrm{H}_{2} \mathrm{SO}_{4}$ used

$\mathrm{M} . \mathrm{E}=$ Equivalence factor $(1.701 / \mathrm{mg})$

\subsection{Determination of the effect of initial ph on the production of antimicrobial substances}

One hundred milliliters of composed MRS Broth was adjusted to initial $\mathrm{pH}$ values of 4.5, 5.5, 6.5 and 7.5, using either $1 \mathrm{M} \mathrm{HCl}$ or $1 \mathrm{M} \mathrm{NaOH}$. Each medium was inoculated with an overnight culture of antimicrobial producing organisms and incubated at $30^{\circ} \mathrm{C}$ for $48 \mathrm{hrs}$; the quantity of antimicrobials produced was estimated using the method of A.O.A.C (2000) as described above for the quantification of antimicrobial substances (Wakil and Osamwonyi, 2012).

\subsection{Determination of the effect of initial temperature on the production of antimicrobial substances}

A modified method of Wakil and Osamwonyi (2012) for the effect of $\mathrm{pH}$ on antimicrobial production and Adesokan et al., (2009) were used. One hundred milliliters of composed MRS Broth was prepared in triplicates. Each medium was inoculated with an overnight culture of antimicrobial producing organisms and incubated at $15^{\circ} \mathrm{C}, 30^{\circ} \mathrm{C}$ and $45^{\circ} \mathrm{C}$ for $48 \mathrm{hrs}$ respectively; the quantity of antimicrobials produced was estimated using the method of A.O.A.C (2000) as described above for the quantification of antimicrobial substances.

2.12. Statistical analysis: All experiments were performed in triplicate and the results are expressed as mean \pm standard deviation and Duncan Multiple Variance analysis $(\mathrm{p}<0.05)$. Data analysis was performed using SPSS 19.0 (IBM Corp., Armonk, NY, USA). 


\section{RESULTS}

3.1. Changes in $\mathbf{p H}$ during fermentation: Changes in $\mathrm{pH}$ during the fermentation of the cassava varieties are presented in Table 1. The $\mathrm{pH}$ ranges from $3.65 \pm 0.56$ to $6.40 \pm 0.06,3.50 \pm 0.02$ to $6.40 \pm 0.06$ for ITI0 and ITI3 respectively. The $\mathrm{pH}$ decreased progressively with fermentation time for the two cassava varieties.

3.2. Changes in TTA during fermentation: The result of TTA $(\mathrm{g} / \mathrm{L})$ during the fermentation of the cassava varieties with respect to fermentation time is presented in Table 2. TTA increases with fermentation time for all the cassava varieties. TTA of the variety ITI0 increased from $0.22 \pm 0.00 \mathrm{~g} / \mathrm{L}$ at $0 \mathrm{hrs}$ to $1.73 \pm 0.10 \mathrm{~g} / \mathrm{L}$ at $96 \mathrm{hrs}$ while the TTA of ITI3 increased from $0.22 \pm 0.00 \mathrm{~g} / \mathrm{L}$ at $0 \mathrm{hrs}$ to $2.83 \pm 0.11 \mathrm{~g} / \mathrm{L}$ at $96 \mathrm{hrs}$.

3.3. Isolation and Enumeration of LAB from the Fermentation Water and Cassava mash: Table 3 and 4 show the plate count obtained on MRS agar for LAB isolated from fermentation supernatant and cassava mash respectively. There was no count detected at $0 \mathrm{hrs}$ of fermentation. The LAB count in fermentation supernatant ranged from $1.2 \pm 0.24 \times 10^{3} \mathrm{CFU} / \mathrm{ml}$ at $12 \mathrm{hrs}$ to $7.5 \pm 0.06 \times 10^{4} \mathrm{CFU} / \mathrm{ml}$ at $96 \mathrm{hrs}$ in ITI0 and $1.0 \pm 0.08 \times 10^{3} \mathrm{CFU} / \mathrm{ml}$ at $12 \mathrm{hrs}$ to $2.1 \pm 0.13 \times 10^{5} \mathrm{CFU} / \mathrm{ml}$ at $96 \mathrm{hrs}$. The LAB count in fermented cassava mash ranged from $1.0 \pm 0.28$ $\mathrm{x} 10^{3} \mathrm{CFU} / \mathrm{g}$ at $12 \mathrm{hrs}$ to $1.8 \pm 0.08 \times 10^{5} \mathrm{CFU} / \mathrm{g}$ at $96 \mathrm{hrs}$ in ITI0 and from $1.2 \pm 0.02 \times 10^{3} \mathrm{CFU} / \mathrm{g}$ at $12 \mathrm{hrs}$ to $1.6 \pm$ $0.23 \times 10^{5} \mathrm{CFU} / \mathrm{g}$ at $96 \mathrm{hrs}$ for ITI3.

3.4. Screening of lactic acid bacteria for antifungal activity: A total of $20 \mathrm{LAB}$ isolates were isolated from both fermentation supernatant and cassava mash of the two cassava varieties on MRS agar at $37^{\circ} \mathrm{C}$ under anaerobic condition. The LAB isolates were screened against selected mould indicator to detect their antifungal activity and the result is shown in Table 5. Out of the 22 isolated LAB, 5 did not show visible inhibition, 3 inhibited fungal growths between $0.1-3 \%$ of plate area, 4 inhibited fungal growth between $3-8 \%$ of plate area while the remaining inhibited fungal growth at a value greater than $8 \%$ of the plate area.

3.5. Identification and Characterization of the isolated LAB: Lactic acid bacterial isolates that shows antifungal activity to the isolated moulds were identified using various physiological and biochemical tests. The LAB isolates were identified as five different genera namely L. casei, L. mesenteroides, L. plantarum, L. acidophilus and L. fermentum. Figure 1 shows the percentage occurrence of the isolated LAB which shows that Lactobacillus plantarum and Lactobacillus mesenteroides are dominant in occurrence with $25 \%$ of occurrence while Lactobacillus acidophilus showed the least percentage of occurrence with $10 \%$ of occurrence.

3.6. Determination of antifungal activity of LAB by agar well diffusion method: The antifungal activity of the selected lactic acid bacteria that inhibited greater than $8 \%$ against growth of spoilage mould of the three cassava products was determined by agar well diffusion method and the results are presented in Table 6. The zones of inhibition were the diameter of the circle formed as a result of the inhibitory activity of LAB isolates against spoilage moulds of cassava products excluding the diameter of the cork borer used $(5.00 \mathrm{~mm})$. The zones of inhibition ranged from $1.00 \mathrm{~mm}$ to $17.30 \mathrm{~mm}$ in diameter. The highest zone of inhibition $(17.30 \mathrm{~mm})$ was from LAB isolate L. plantarum (WLW103) against mould isolate WFE101 while the lowest zone of inhibition (1.00 $\mathrm{mm}$ ) was from the LAB isolate L. fermentum (YLW102) against the mould isolate YFE103. Aspergillus niger showed the highest susceptibility and Rhizopus $s p$. showed the least susceptibility to the LAB isolates.

Out of the 9 LAB isolates, only isolates L. plantarum (YLM102), L. plantarum (WLW103), L. plantarum (WLW107) and L. acidophilus (WLM101) showed inhibition against more than 50\% of the mould isolates. Isolates L. acidophilus (WLM101) and linhibited 19 mould isolates out of 21 accounting to 90.47\%. Mould isolates YFF102 and YFL 102 are the least inhibited. YFF102 was only inhibited by LAB isolate L. plantarum (WLW107) while YFL102 was inhibited by only by L. plantarum (WLW103). It was also observed that LAB isolates from ITI3 cassava variety were greatly active against moulds isolated from ITI0 while LAB isolate from ITI0 were mildly active against moulds of other cassava variety as they showed better activity against the mould isolated from them.

3.7. Molecular Characterization of LAB: Molecular techniques was also used to identify the LAB with highest and lowest antifungal activity. The LAB isolates were sequenced and BLAST to be Lactobacillus fermentum NBRC15885 (YLW102), Lactobacillus plantarum NRRLB-14768 (YLW104), Lactobacillus plantarum NBRC15891 (YLM102), Lactobacillus acidophilus VPI6032 (WLW105) and Lactobacillus plantarum NBRC15891 (WLW107).

The antifungal metabolites were quantified by titration. The quantity $(\mathrm{g} / \mathrm{L})$ of antifungal metabolites responsible for the antifungal activities of the LAB isolates against spoilage moulds is shown in Table 7. 
3.8. Quantitative estimation of antifungal metabolites: The antifungal metabolites detected were lactic acid, diacetyl and hydrogen peroxide. The highest quantities of the metabolites were produce at 48 hrs of incubation after which there was a general reduction in the quantity of metabolites produced at incubation time higher than that.

The peak lactic acid produced at $48 \mathrm{hrs}$ was $1.28 \mathrm{~g} / \mathrm{L}$ by Lactobacillus plantarum (WLW103) while the least was $0.52 \mathrm{~g} / \mathrm{L}$ by Lactobacillus fermentum (YLW102). The highest diacetyl quantity produced at $48 \mathrm{hrs}$ was $1.92 \mathrm{~g} / \mathrm{L}$ by Lactobacillus plantarum (WLW103) with the lowest being $0.88 \mathrm{~g} / \mathrm{L}$ by Lactobacillus plantarum (WLW107). The highest quantity of hydrogen peroxide produced at $48 \mathrm{hrs}$ was quantified as $0.039 \mathrm{~g} / \mathrm{L}$ by Lactobacillus mesenteroides (YLW103) and Lactobacillus mesenteroides (YLW103) with the lowest produced by Lactobacillus plantarum (YLM102) of $0.043 \mathrm{~g} / \mathrm{L}$ quantity.

3.9. The effect of $\mathbf{p H}$ and Temperature on antifungal metabolites production: The optimization of the production of antifungal metabolites with varying temperature and $\mathrm{pH}$ was also determined. The $\mathrm{pH}$ of the medium was varied to $\mathrm{pH} 4.5,5.5,6.5$ and 7.5. The result of the optimization of antifungal metabolite quantification with varying $\mathrm{pH}$ is shown in Table 8. It was observed that all the antifungal metabolites were optimally produced in the acidic $\mathrm{pH}$ with highest performance at $\mathrm{pH} 5.5$ and general reduction at $\mathrm{pH}$ greater than that. The highest quantity of lactic acid produced at pH 5.5 was quantified as $1.42 \mathrm{~g} / \mathrm{L}$ by Lactobacillus plantarum (WLW107) with the lowest produced by Lactobacillus casei (YLM101) of $0.95 \mathrm{~g} / \mathrm{L}$ quantity

The peak diacetyl quantity produced at $\mathrm{pH} 5.5$ was $2.86 \mathrm{~g} / \mathrm{L}$ by Lactobacillus acidophilus (WLM101) with the lowest being $1.01 \mathrm{~g} / \mathrm{L}$ by Lactobacillus plantarum (YLM102). The highest quantity of hydrogen peroxide produced at pH 5.5 was quantified as $0.085 \mathrm{~g} / \mathrm{L}$ by Lactobacillus mesenteroides (YLW103) with the lowest produced by Lactobacillus casei (YLM101) of $0.021 \mathrm{~g} / \mathrm{L}$ quantity. The quantification of the antifungal metabolites was done at $15^{\circ} \mathrm{C}, 30^{\circ} \mathrm{C}$ and $45^{\circ} \mathrm{C}$. Table 9 shows the effect of temperature on the quantity of antifungal metabolites produced. It was observed that the production of the antifungal metabolites was optimally produced at $30^{\circ} \mathrm{C}$. The highest quantity of lactic acid produced at $30^{\circ} \mathrm{C}$ was $1.32 \mathrm{~g} / \mathrm{L}$ by Lactobacillus fermentum (YLW102) while the least was $0.88 \mathrm{~g} / \mathrm{L}$ by Lactobacillus plantarum (WLW107). The peak diacetyl quantity produced at $30^{\circ} \mathrm{C}$ was $2.53 \mathrm{~g} / \mathrm{L}$ by Lactobacillus plantarum (WLW103) with the lowest being $1.01 \mathrm{~g} / \mathrm{L}$ by Lactobacillus frementum (YLW102). The highest quantity of hydrogen peroxide produced at $30^{\circ} \mathrm{C}$ was quantified as $0.054 \mathrm{~g} / \mathrm{L}$ by Lactobacillus mesenteroides (YLW103) with the lowest produced by Lactobacillus plantarum (YLW104) of 0.018 g/L quantity.

Table 1: $\mathbf{p H}$ of the cassava varieties during fermentation

\begin{tabular}{lll}
\hline Cassava varieties & \multicolumn{2}{c}{ ITI3 } \\
\cline { 2 - 3 } 0 & ITI0 & $6.40 \pm 0.06$ \\
12 & $6.40 \pm 0.06$ & $5.10 \pm 0.10$ \\
24 & $5.20 \pm 0.12$ & $4.20 \pm 0.33$ \\
36 & $4.45 \pm 0.03$ & $3.95 \pm 0.10$ \\
48 & $4.05 \pm 0.03$ & $3.88 \pm 0.12$ \\
60 & $3.95 \pm 0.08$ & $3.75 \pm 0.09$ \\
72 & $3.80 \pm 0.15$ & $3.72 \pm 0.22$ \\
84 & $3.76 \pm 0.13$ & $3.70 \pm 0.08$ \\
96 & $3.75 \pm 0.76$ & $3.50 \pm 0.02$ \\
\hline
\end{tabular}

Table 2: TTA of the different cassava varieties during fermentation

\begin{tabular}{lll}
\hline Cassava varieties & \multicolumn{2}{l}{} \\
\cline { 2 - 3 } 0 & ITI0 & ITI3 \\
\cline { 2 - 3 } 12 & $0.22 \pm 0.00$ & $0.22 \pm 0.00$ \\
24 & $0.71 \pm 0.17$ & $0.75 \pm 0.23$ \\
36 & $1.08 \pm 0.16$ & $1.08 \pm 0.12$ \\
48 & $1.20 \pm 0.17$ & $1.35 \pm 0.25$ \\
60 & $1.20 \pm 0.17$ & $1.35 \pm 0.25$ \\
72 & $1.35 \pm 0.23$ & $1.40 \pm 0.10$ \\
84 & $1.38 \pm 0.15$ & $1.62 \pm 0.16$ \\
96 & $1.51 \pm 0.06$ & $1.85 \pm 0.23$ \\
\hline
\end{tabular}


Table 3: Lactic Acid Bacteria count of fermentation supernatant during fermentation Microbial Count LogCFU/ml

\section{Hours}

0

12

24

36

48

60

72

84

96

\begin{tabular}{ll}
\hline ITI0 & ITI3 \\
\hline ND & ND \\
$1.2 \pm 0.24 \times 10^{3}$ & $1.0 \pm 0.08 \times 10^{3}$ \\
$1.6 \pm 0.05 \times 10^{3}$ & $2.1 \pm 0.02 \times 10^{3}$ \\
$2.8 \pm 0.30 \times 10^{4}$ & $3.0 \pm 0.07 \times 10^{4}$ \\
$4.0 \pm 0.15 \times 10^{4}$ & $4.3 \pm 0.31 \times 10^{4}$ \\
$5.2 \pm 0.14 \times 10^{4}$ & $5.8 \pm 0.15 \times 10^{4}$ \\
$1.9 \pm 0.05 \times 10^{5}$ & $7.2 \pm 0.49 \times 10^{4}$ \\
$1.2 \pm 0.23 \times 10^{5}$ & $1.1 \pm 0.30 \times 10^{5}$ \\
$7.5 \pm 0.06 \times 10^{4}$ & $2.1 \pm 0.13 \times 10^{5}$
\end{tabular}

Table 4: Lactic Acid Bacteria count of Cassava mash during fermentation

\section{Microbial Count LogCFU/ml}

Hours

0

12

24

36

48

60

72

84

96

\begin{tabular}{ll}
\hline ITI0 & ITI3 \\
\hline ND & ND \\
$1.0 \pm 0.28 \times 10^{3}$ & $1.2 \pm 0.02 \times 10^{3}$ \\
$1.4 \pm 0.21 \times 10^{3}$ & $1.5 \pm 0.07 \times 10^{3}$ \\
$3.0 \pm 0.16 \times 10^{3}$ & $3.2 \pm 0.08 \times 10^{3}$ \\
$4.1 \pm 0.40 \times 10^{3}$ & $4.2 \pm 0.06 \times 10^{3}$ \\
$1.6 \pm 0.25 \times 10^{4}$ & $1.4 \pm 0.04 \times 10^{4}$ \\
$1.7 \pm 0.25 \times 10^{4}$ & $1.8 \pm 0.04 \times 10^{4}$ \\
$1.2 \pm 0.04 \times 10^{5}$ & $1.9 \pm 0.30 \times 10^{4}$ \\
$1.8 \pm 0.08 \times 10^{5}$ & $1.6 \pm 0.23 \times 10^{5}$
\end{tabular}

Table 5: Screening of lactic acid bacteria for antifungal activity.

\begin{tabular}{llll}
\hline S/N & Variety & Isolate code & Activity \\
\hline 1 & ITI0 & YLW101 & - \\
2 & YLW102 & ++ \\
3 & & YLW103 & + \\
4 & YLW104 & ++ \\
5 & YLW105 & ++ \\
6 & YLM101 & +++ \\
7 & & YLM102 & - \\
8 & YLM103 & + \\
9 & YLM104 & ++ \\
10 & WLW101 & ++ \\
11 & WLW102 & +++ \\
12 & WLW103 & - \\
13 & & WLW104 & +++ \\
14 & & WLW105 & ++ \\
15 & & WLW106 & +++ \\
16 & & WLW107 & +++ \\
17 & & WLM101 & - \\
18 & & WLM102 & ++ \\
19 & & WLM103 & - \\
\hline
\end{tabular}


Table 6: Diameter of zones of inhibition ( $\mathrm{mm}$ ) of Mould isolates by LAB isolates

\section{LAB ISOLATES}

\begin{tabular}{|c|c|c|c|c|c|c|c|c|c|}
\hline 흘 & $\frac{\tilde{O}}{\partial}$ & $\overbrace{\lambda}^{\infty}$ & 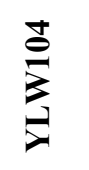 & $\underset{\partial}{\stackrel{\Xi}{\partial}}$ & 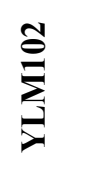 & $\frac{\mathscr{\theta}}{3}$ & $\stackrel{6}{0}$ & $\frac{\hat{\theta}}{3}$ & $\underset{j}{\bar{B}}$ \\
\hline YFF101 & - & - & 2.7 & - & 3.0 & 4.7 & 9.3 & 4.0 & 8.0 \\
\hline YFF102 & - & - & - & - & - & - & - & 4.3 & - \\
\hline YFF103 & - & - & 10.0 & 4.3 & 8.3 & 8.0 & 11.7 & 4.0 & 5.3 \\
\hline YFF104 & - & - & - & - & 4.0 & 5.3 & - & 9.7 & 5.7 \\
\hline YFF105 & - & 4.7 & 11.7 & 9.3 & 8.7 & 17.6 & - & - & 5.7 \\
\hline YFE101 & - & - & 12.0 & 5.0 & 10.0 & 5.3 & 3.3 & - & 10.0 \\
\hline YFE102 & - & - & - & - & - & 11.7 & 10.0 & - & 4.0 \\
\hline YFE103 & 2.0 & 3.0 & - & - & - & 6.3 & - & 8.3 & 7.3 \\
\hline YFE104 & - & 5.0 & - & 10.0 & - & - & 4.0 & - & 2.3 \\
\hline YFL101 & - & - & - & - & - & 6.7 & - & 12.0 & 10.0 \\
\hline YFL102 & - & - & - & - & - & 2.3 & - & - & - \\
\hline YFL103 & 4.0 & 3.0 & - & - & 6.0 & 3.0 & 5.0 & 2.0 & 4.0 \\
\hline YFL104 & - & - & - & 3.0 & 5.0 & 2.0 & 5.0 & 2.0 & 6.0 \\
\hline YFL105 & - & 6.3 & - & 8.0 & - & - & 7.0 & - & 5.7 \\
\hline WFF101 & - & - & - & - & - & 10.3 & - & - & 10.3 \\
\hline WFF 102 & - & - & - & - & 5.0 & 7.3 & 5.0 & 4.5 & 7.3 \\
\hline WFE101 & - & - & 3.0 & - & - & 17.3 & - & 10.0 & 8.3 \\
\hline WFE102 & - & - & - & - & 4.3 & 14.3 & - & 10.0 & 8.0 \\
\hline WFL101 & 7.7 & - & - & - & - & 10.7 & 10.0 & - & 9.3 \\
\hline WFL102 & 9.0 & - & - & - & 5.0 & 11.7 & - & - & 9.0 \\
\hline WFL103 & 9.7 & - & - & - & 7.0 & 10.3 & - & - & 6.5 \\
\hline
\end{tabular}


Table 7: Quantity of Lactic Acid (g/L), Diacetyl (g/L) and Hydrogen peroxide (g/L) produced by the LAB isolates from the twocassava varieties at different incubation time

\begin{tabular}{|c|c|c|c|c|c|c|c|c|c|c|c|c|c|}
\hline \multirow[t]{2}{*}{$\mathbf{S} / \mathbf{N}$} & \multirow{2}{*}{$\begin{array}{c}\text { Isolates } \\
\text { code }\end{array}$} & \multicolumn{4}{|c|}{ Lactic acid (g/L) } & \multicolumn{4}{|c|}{ Diacetyl (g/L) } & \multicolumn{4}{|c|}{ Hydrogen peroxide (g/L) } \\
\hline & & $24 \mathrm{hrs}$ & $48 \mathrm{hrs}$ & $72 \mathrm{hrs}$ & $96 \mathrm{hrs}$ & $24 \mathrm{hrs}$ & $48 \mathrm{hrs}$ & $72 \mathrm{hrs}$ & $96 \mathrm{hrs}$ & $24 \mathrm{hrs}$ & $48 \mathrm{hrs}$ & $72 \mathrm{hrs}$ & $96 \mathrm{hrs}$ \\
\hline 1 & YLW102 & 0.17 & 0.52 & 0.48 & 0.40 & 0.92 & 1.32 & 1.24 & 0.97 & 0.015 & 0.023 & 0.018 & 0.014 \\
\hline 2 & YLW103 & 0.25 & 0.91 & 0.90 & 0.83 & 0.98 & 1.21 & 1.10 & 0.73 & 0.027 & 0.039 & 0.015 & 0.008 \\
\hline 3 & YLW104 & 0.46 & 1.01 & 0.93 & 0.73 & 0.76 & 0.99 & 0.84 & 0.65 & 0.007 & 0.016 & 0.012 & 0.009 \\
\hline 4 & YLM101 & 0.22 & 0.56 & 0.52 & 0.49 & 0.97 & 1.06 & 1.04 & 1.01 & 0.019 & 0.025 & 0.018 & 0.012 \\
\hline 5 & YLM102 & 0.26 & 0.92 & 0.82 & 0.74 & 0.79 & 0.93 & 0.88 & 0.81 & 0.008 & 0.014 & 0.014 & 0.011 \\
\hline 6 & WLW103 & 0.69 & 1.28 & 1.19 & 1.05 & 0.87 & 1.92 & 1.51 & 1.20 & 0.018 & 0.029 & 0.021 & 0.019 \\
\hline 7 & WLW105 & 0.64 & 0.82 & 0.74 & 0.63 & 0.75 & 1.10 & 0.96 & 0.83 & 0.015 & 0.022 & 0.019 & 0.014 \\
\hline 8 & WLW107 & 0.72 & 1.05 & 0.97 & 0.86 & 0.46 & 0.88 & 0.83 & 0.64 & 0.014 & 0.021 & 0.015 & 0.009 \\
\hline 9 & WLM101 & 0.26 & 0.97 & 0.94 & 0.90 & 0.73 & 1.20 & 0.91 & 0.83 & 0.008 & 0.028 & 0.022 & 0.013 \\
\hline
\end{tabular}

Table 8: The effect of initial ph on production of Lactic Acid (g/L), Diacetyl (g/LO and Hydrogen peroxide $(\mathrm{g} / \mathrm{L})$ by the $\mathrm{LAB}$ isolates

\begin{tabular}{|c|c|c|c|c|c|c|c|c|c|c|c|c|c|}
\hline \multirow[t]{2}{*}{$\mathbf{S} / \mathbf{N}$} & \multirow{2}{*}{$\begin{array}{l}\text { Isolates } \\
\text { code }\end{array}$} & \multicolumn{3}{|c|}{ Lactic acid $(g / L)$} & \multicolumn{4}{|c|}{ Diacetyl (g/L) } & \multicolumn{5}{|c|}{ Hydrogen peroxide (g/L) } \\
\hline & & ph4.5 & ph5.5 & ph6.5 & ph7.5 & ph4.5 & ph5.5 & ph6.5 & ph7.5 & ph4.5 & ph5.5 & ph6.5 & ph7.5 \\
\hline 1 & YLW102 & 0.35 & 0.71 & 0.57 & 0.45 & 0.81 & 1.52 & 0.94 & 0.72 & 0.018 & 0.026 & 0.021 & 0.021 \\
\hline 2 & YLW103 & 0.45 & 1.10 & 0.92 & 0.85 & 0.89 & 1.34 & 1.21 & 0.78 & 0.036 & 0.085 & 0.046 & 0.035 \\
\hline 3 & YLW104 & 0.75 & 1.34 & 1.18 & 1.08 & 0.75 & 1.23 & 1.08 & 1.08 & 0.013 & 0.025 & 0.015 & 0.013 \\
\hline 4 & YLM101 & 0.53 & 0.95 & 0.61 & 0.41 & 1.23 & 1.65 & 1.23 & 1.12 & 0.016 & 0.021 & 0.019 & 0.019 \\
\hline 5 & YLM102 & 0.51 & 1.01 & 0.91 & 0.45 & 0.87 & 1.01 & 0.91 & 0.86 & 0.024 & 0.056 & 0.028 & 0.021 \\
\hline 6 & WLW103 & 0.91 & 1.34 & 1.21 & 1.09 & 1.14 & 2.13 & 1.83 & 1.21 & 0.019 & 0.036 & 0.024 & 0.017 \\
\hline 7 & WLW105 & 0.54 & 1.08 & 0.95 & 0.57 & 1.12 & 2.53 & 1.63 & 1.10 & 0.021 & 0.044 & 0.029 & 0.021 \\
\hline 8 & WLW107 & 0.97 & 1.42 & 1.18 & 0.79 & 1.35 & 2.47 & 1.98 & 1.42 & 0.017 & 0.036 & 0.013 & 0.028 \\
\hline 9 & WLM101 & 0.54 & 1.08 & 1.01 & 0.97 & 1.10 & 2.86 & 1.52 & 0.94 & 0.015 & 0.028 & 0.019 & 0.019 \\
\hline
\end{tabular}

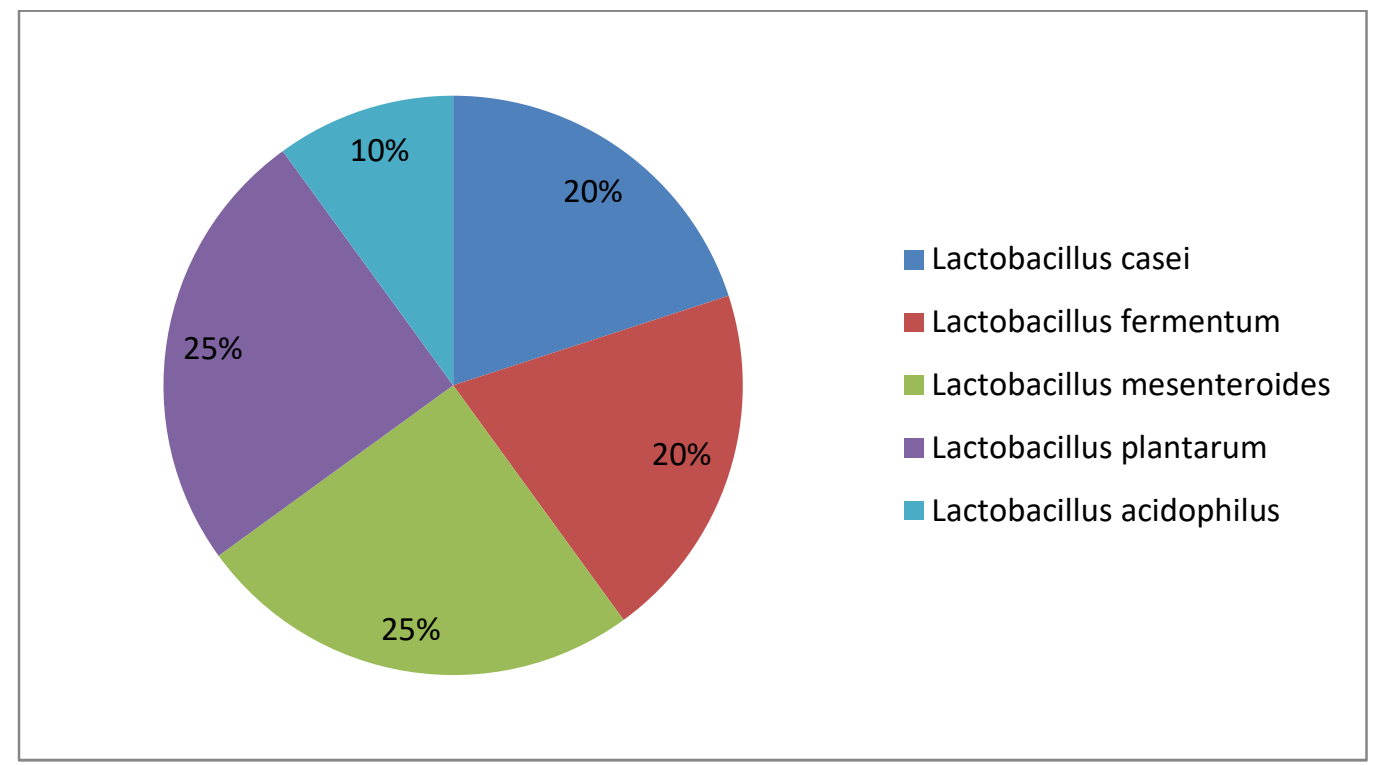

Figure 1: Percentage occurrence of LAB isolates from fermentation supernatant and cassava mash

\section{DISCUSSION}

The nutritional and organoleptic qualities of fermented products such as Ogi, Eko, Garri, Lafun and Fufu are usually as a result of the interactions between different organisms (Omemu et al., 2007). The interactions may be beneficial adding to the final product by means of desirable biochemical changes like the production of aromatic compounds and enzymatic activities (Viljoen, 2001). On the other hand, the interactions may be detrimental causing spoilage by inhibiting the growth of starter cultures and producing off-flavors, or discoloration (Omemu et al., 2007). 
The varying value in $\mathrm{pH}$ and titratable acidity observed in this study have been reported by several authors to be a major characteristic of the fermentation of carbohydrate rich raw materials like tubers, roots and cereal which is in line with the findings of Adesokan et al. (2009) and Wakil and Osamwonyi (2012). The decrease in pH and increase in TTA is due to the activity of Lactic acid bacteria producing organic acid primarily lactic acid which is a common characteristic of fermenting wet mash (Raimbault, 1995; Wakil and Osamwonyi, 2012).

The high population of LAB in the fermentation of these cassava varieties indicates that they are predominant microorganisms responsible for the fermentation of the cassava roots and this is in agreement with the works of works of Obadina et al. (2006) and Krabi et al.(2016) who in their various studies recorded a high LAB count in the fermentation of cassava and cassava products. It is also an indication that the LAB proliferation is not affected by the low $\mathrm{pH}$ of these food products which means they can utilize the substrate content of the cassava roots.

The lactic acid bacteria were identified culturally, morphologically, physiologically and biochemically as $L$. casei, L. mesenteroides, L. plantarum, L. acidophilus and L. fermentum with L. plantarum being the predominant one and this agrees with the work of Adesokan et al. (2009) who reported predominant of this organism in spontaneous fermentation of cereal and roots. Species of Aspergillus are the most common isolates obtained from the spoilt food samples. This is in agreement with the report of Aderiye et al. (2006) and Omemu et al. (2015) who in their various studies isolated mold in some stored fermented foods. The presence of mould such as Aspergillus niger, Aspergillus flavus, Rhizopus sp. and Penicillium sp. during the spoilage of Garri, Lafun and Fufu agrees with the findings of Ishola and Adebayo-Tayo (2012) and Rosales-soto (2012), where they isolated these organisms from $f u f u$ samples.

The increasing need for food safety and security has been a major concern in the public health sector. Many filamentous mould such as Aspergillus niger, Aspergillus flavus, Rhizopus sp. and Penicillium sp. have been implicated in food spoilage (Omemu et al., 2015). The traditional method of tackling this problem was the use of chemical antifungal which have resulted in the development of antifungal resistance strains of these spoilage organisms. Draksler et al. (2004) and Pounce et al. (2008) also reported that the inhibition of mould by LAB may be as a result of the low $\mathrm{pH}$ due to the organic acid production which can result in the increase of the production of hydrogen peroxide. The inhibition of the moulds by the isolates was at varying degrees which is in consonance with the work of Kalalou et al. (2004) and Toyi (2014) in their various studies where they observed varying degrees of inhibition of various food borne pathogens by CFS of LAB.

All the LAB isolates produced lactic acid, diacetyl and hydrogen peroxide with highest production at $48 \mathrm{hrs}$ of incubation. L plantarum having highest production of lactic acid while Lactobacillus fermentum had the least. The highest diacetyl was also produced by Lactobacillus plantarum and the least produced by Lactobacillus plantarum also. The highest amount of hydrogen peroxide was produced by Lactobacillus plantarum and Lactobacillus mesenteroideswith the lowest produced by Lactobacillus plantarum. These results were in agreement with the works of Afolabi et al. (2008), Adesokan et. al. (2009), Wakil and Osmawonyi (2012) and Ishola and Adebayo-Tayo (2012) who in their various studies reported that antimicrobial metabolites of LAB are optimally produced at $48 \mathrm{hrs}$ of incubation with L. plantarum producing the highest quantity of lactic acid. In similar studies, Wakil and Osamwonyi (2012) had reported high amount of hydrogen peroxide being produced by Lactobacillus mesenteroides and that Lactobacillus plantarum produced the least quantity of diacetyl in his studies. Ogunbanwo et al. (2004) also obtained a similar result for L.plantarum isolated from $f u f u$, a traditional fermented cassava product.

The hydrogen peroxide produced adds to the antimicrobial activity of LAB and in some cases be a precursor for the production of other potent antimicrobial compounds such as super oxide $\left(\mathrm{O}^{-}{ }^{-}\right.$and hydroxyl $\left(\mathrm{OH}^{-}\right) \mathrm{radicals}$ (Wakil and Osamwonyi, 2012). The antimicrobial effect of hydrogen peroxide may result from the oxidation of sulfhydryl groups causing denaturing of a number of enzymes, and from the peroxidation of membrane lipids thus they increased membrane permeability (Wakil and Osamwonyi, 2012). Nettles and Barefoot (1993) reported that hydrogen peroxide accumulates in cultures of Lactobacillus, Leuconostoc and Pediococcus species. Diacetyl which is mainly produced by lactic acid bacteria including strains of Leuconostoc, Lactococcus, Pediococcus and Lactobacillus is effective against bacteria (Schnurer and Magnusson, 2005). In fermented foods, LAB plays an important role in the rheological and flavoring quality of the fermented product (Olatunde, 2016). They are able to perform this role because of the production of diacetyl, which contribute to the typical flavor and taste of many foods, particularly dairy products and their antagonistic activity has been partly traced to the antimicrobial properties of diacetyl (Wakil and Osamwonyi, 2012).

The result of this research gives evidence that antifungal producing $\mathrm{LAB}$ are found in the fermentation of pro-vitamin A and white root cassava and these isolates have the ability to survive in a low $\mathrm{pH}$. The effect of $\mathrm{pH}$ and temperature on the production of the lactic acid, diacetyl and hydrogen peroxide was investigated. The initial $\mathrm{pH}$ of the culture medium was observed to affect the production of antifungal substances by LAB. After varying the initial $\mathrm{pH}$ of the medium and allowing the same incubation time for all the isolates, it was evident that there was a difference in the amount of antifungal substances produced. The acidic range of $\mathrm{pH}$ was seen to favor production of antifungal substances. 
The maximum production of antifungal substances occurred at $\mathrm{pH} 5.5$ which is agreement with the results of Afolabi et al. (2008) and Wakil and Osamwonyi (2012). The optimum pH for the growth of LAB is 5.5 and at this $\mathrm{pH}$ the quantity of antifungal substances produced was highest. The production of antifungal metabolites in adjusted $\mathrm{pH}$ medium decreases with increasing $\mathrm{pH}$ greater than $\mathrm{pH}$ 5.5. These results indicate that the antifungal substances are greatly favoured by acidic medium with optimal $\mathrm{pH}$ of 5.5. Also, the antifungal substances are greatly produced at $30^{\circ} \mathrm{C}$ above which there is a decline. This is in agreement with the work of Adesokan et al. (2009) who reported similar cases in their various studies that optimum temperature and $\mathrm{pH}$ for antimicrobial metabolites production in $\mathrm{LAB}$ is $30^{\circ} \mathrm{C}$ and $\mathrm{pH} 5.5$ respectively. This also indicates that the quantity of antifungal produced is a function of the LAB to survive in the culture medium.

Five lactic acid bacteria isolates were selected based on their antifungal activities for molecular analysis using the 16S rRNA partial sequencing for DNA extraction. This is necessary in order to properly identify the LAB isolates involved in the fermentation of the three cassava varieties. Identification of LAB by 16s rRNA has been referred to as a very reliable method and has been used for their identification by several authors like kostinek et al., (2005) and Oguntoyinbo and Narbad, (2012). Molecular techniques, especially Polymerase Chain reaction (PCR) based methods are important for the specific characterization and detection of LAB strains (Adiguzel and Atasever, 2009; Lawalata et al., 2011 and Mohania et al., 2008). The 16S rRNA gene sequencing and BLAST searching at the NCBI identified the isolates as different strains of Lactobacillus plantarum, lactobacillus fermentum and Lactobacillus acidophilus. Many strains of these lactic acid bacteria have been reported by many authors to produce antifungal activities and have been isolated from fermented foods (Wakil and Osamwonyi, 2012; Adesokan et al. 2009 and Afolabi et al. 2008).

In conclusion, the research on the antifungal activities of LAB isolated from cassava fermentation especially on pro-vitamin A cassava is still novel as there were paucity of information on them as at the time of conducting this research. The application of the antifungal substances from LAB as bio-preservatives which are consumer friendly is highly significant because of their non toxic nature compared to the current chemical antifungal substances. Since LAB is among the Generally Regarded As Safe (GRAS) microorganisms, they may be exploited for the control of spoilage mould as indicated from these results. Lactic acid bacteria and their metabolites have been described to be more effective in numerous applications. Most antifungal substances produced by LAB are safe and effective natural inhibitors of food spoilage mould in various fermented foods. These isolated strains can positively have impact on use as starter cultures for traditional fermented foods, with a perspective to improve the shelf life, nutritional values and safety of such foods. There are mixed cultures of LAB species during the fermentation of the three cassava varieties used in this study. This research work has confirmed that Lactobacillus plantarum, Lactobacillus fermentum, Lactobacillus caesi and Lactobacillus acidophilus are good producer of lactic acid, diacetyl and hydrogen peroxide. Due to this fact, these microorganisms are among the microorganisms Generally Recognized As Safe (GRAS) for fermentation and bio-preservative applications. However, more species of bacteria should also be further analyzed for antifungal properties.

\section{ACKNOWLEDGMENTS}

This research was supported by the Cassava Breeding Unit, International Institute of Tropical Agriculture (IITA), Ibadan, Oyo State, Nigeria. Its contents are solely the responsibility of the authors and do not represent the official views of the Cassava Breeding Unit, IITA, Ibadan, Oyo State, Nigeria. We would also like to thank Dr. O. R. Afolabi and Mrs C. O. Ojesola of the Department of Microbiology, College of Biosciences, Federal University of Agriculture, Abeokuta, Ogun State, Nigeria for the laboratory efforts rendered.

\section{REFERENCES}

Adiguzel GC and Atasever M (2009). Phenotypic and Genotypic Characterization of Lactic Acid Bacteria Isolated from Turkish Dry Fermented Sausage. Romanian Biotechnological Letters 14(1):4130-4138.

Aderiye BI, Laleye SA and Akinduro HA (2006). Spoilage of Some Stored Fermented Foods in Southwest Nigeria. Journal of Biological Science 6:659-663.

Adesokan IA, Odetoyinbo BB and Okanlawon BM (2009). Optimization of Lactic Acid Production by LAB Isolated from Some Traditional Fermented Food in Nigeria. Pakistan Journal of Nutrition 8(25):611-618.

Afolabi OR, Bankole OM and Olaitan OJ (2008). Production and characterization of antimicrobial agents by Lactic Acid Bacteria Isolated from Fermented Foods. The Internet Journal of Microbiology 4(2):1-7.

Akinwumi A (2011). Pro Vitamin A Cassava: a revolution for nutrition and health in Nigeria. Speech delivered by Honourable Minister of Agriculture and Rural Development, at the launch of the Pro-Vitamin A Cassava Varieties, held at the National Root Crops Research Institute, Umudike, Abia State.

Antara NS, Dibia IN and Aryanta WR (2009). Characterization of lactic acid bacteria isolated from horse milk of bima. Agricultural Technology 29(1):1-9.

Anto B, Arina TL and Siti NJ (2005). Isolation and Screening of Lactic Acid Bacteria from Fermented Foods. Jurnal Sains \& Matematika (JSM) 13(3):121 -124. 
AOAC (2000). Official Methods of Analysis. 17th ed. Gaithersburg, MD, USA: AOAC.

Bai V, Remadevi T, Bala N and Janard JS (2010). Effect of processing on the retention of carotenoids in yellowfleshed cassava (Manihot esculenta Crantz) roots. International Journal of Food Science and Technology 46:166-169.

Bhattacharyya BK (2009). Emergence of Probiotics in Therapeutic Applications. International Journal of Pharmaceutical Sciences and Nanotechnology. 2(1):383-389.

Boaventura C, Azevedo R, Uetanabaro A, Nicoli J and Braga LG (2012). The Benefits of Probiotics in Human and Animal Nutrition. New Advances in the Basic and Clinical Gastroenterology. Retrieved on $23^{\text {rd }}$ May, 2016 from www.Intechopen.Com. Pg.75-101.

Chiona M, Ntawuruhunga P, Benesi IRM, Matumba L and Moyo CC (2014). Aflatoxins contamination in processed cassava in Malawi and Zambia. African Journal of Food, Agriculture, Nutrition and Development 14(3):8809-8820.

Draskler D, Gonzales S and Oliver G (2004). Preliminary Assays for the Development of a Probiotic for Goats. Reproduction Nutrition Development 44:397-405

Edem DO, Ayatse JOI and Itam EH (2001). Effect of soy protein supplementation on the nutritive value of garri farina from Manihot esculenta. Food Chemistry 75:57-62.

Ennahar S, Sashihara T, Sonomoto K and Ishizaki A (2000). Class IIa Bacteriocins: Biosynthesis, Structure and Activity. FEMS Microbiology Review 24:85-106.

FAO (2005). A review of cassava in Africa with country case studies on Niger, Ghana, the United Republic of Tanzania, Uganda and Benin. Validation forum on the global cassava development strategy, April 26-28, Food and Agriculture Organization, Rome, Italy. www.fao.org.

Gacheru PK, Abong GO, Okoth MW, Lamuka PO, Shibairo, SA and Katama CKM (2016). Microbiological Safety and Quality of Dried Cassava Chips and Flour Sold in the Nairobi and Coastal Regions Of Kenya. African Crop Science Journal. 24:137-143.

Githunguri CM, Mwiti S and Migwa Y (2007). Cyanogenic potentials of early bulking Cassava planted at Katumani, a semi-arid area of Eastern Kenya. Africa Crop Science Conference Proceedings 8:925-927.

Harun-Ur-Rashid MD, Togo K, Ueda M and Miyamoto T (2009). Probiotic Characteristics of Lactic Acid Bacteria Isolated From Traditional Fermented Milk 'Dahi' In Bangladesh. Pakistan Journal of Nutrition 6(6):647-652.

Ishola RO and Adebayo-Tayo BC (2012). Screening of Lactic Acid Bacteria Isolated from Fermented Food for Bio-molecules Production. AU Journal of Technology 15(4):205-217.

Kapil A (2005). The Challenge of Antibiotic Resistance: Need to Contemplate. Indian Journal of Medical Research 121:83-91.

Kalalou I, Faid M and Ahmani AT (2004). Extending shelf life of fresh minced camel meat at ambient temperature by Lactobacillus delbrueckii subsp. delbrueckii. Electronic Journal of Biotechnology 7(3):0717-3458.

Kiura JN, Mutegi CK, Kibet P and Danda MK (2005). Cassava production, utilization and marketing in Coastal Kenya. A report of a survey on cassava enterprise conducted between July and October 2003 in Kwale, Kilifi, Mombasa and Malindi Districts. Internal report no.35, KARLO-Mtwapa, Kenya.

Kostinek M, Specht I, Edward V, Schillinger U, Hertel C and Holzapfel W (2005). Diversity and technological properties of predominant lactic acid bacteria from fermented cassava used for the preparation of Gari, a traditional African food. Systematic and Applied Microbiology 28: 527-40.

Krabi ER, Assamoi AA, Ehon AF, Amani NG, Niamké LS, Cnockaert M, Aerts M and Vandamme P (2016). Biochemical properties of three lactic acid bacteria strains isolated from traditional cassava starters used for attieke preparation. African Journal of Food Science 10(11): 271-277. DOI: 10.5897/AJFS2016.1430

Lasagno M, Beoletto V, Sesma F, Raya R, Font De Valdez G and Eraso A (2002). Selection of Bacteriocin Producer Strains of Lactic Acid Bacteria from a Dairy environment. Microbiologia 25:37-44.

Lavermicocca P, Valerio, F and Visconti A (2003). Antifungal activity of phenyllactic acid against molds isolated from bakery products. Applied and Environmental Microbiology 69 (1): 634-640

Lawalata HJ, Sembiring L and Rahayu ES (2011). Molecular Identification of Lactic Acid Bacteria Producing Antimicrobial Agents from Bakasang, an Indonesian Traditional Fermented Fish Product. Indonesian Journal of Biotechnology 16(2): 93-99

Manjula K, Hell K, Fandohan P, Abass A and Bandyopadhyay R (2009). Aflatoxin and Fumonisin contamination of cassava products and maize grain from markets in Tanzania and Republic of the Congo. Toxin Reviews $2: 63-69$.

McAluiffe O, Ross RP and Hill C (2001). Lantibiotics: Structure, Biosynthesis and Mode of Action. FEMS Microbiology Review 25:285-308.

Mohania D, Nagpal R, Kumar M, Bhardwaj A, Yadav M, Jain S, Marotta F, Singh V, Parkash OM and Yadav H (2008). Molecular Approaches for Identification and Characterization of Lactic Acid Bacteria. Journal of Digestive Diseases 9:190-198.

Muhialdin BJ, Zaiton H and Nazamid S (2013). Lactic Acid Bacteria in Biopreservation and the Enhancement of 
the Functional Quality of Bread." INTECH. Chapter 6.

Nettles CG and Barefoot A (1993). Biochemical and genetic characteristics of bacteriocins of food associated lactic acid bacteria. Journal Food Protection 56:338-356.

Obadina AO, Oyewole OB, Sanni LO and Abiola SS (2006). Fungal enrichment of cassava peels proteins. African Journal of Biotechnology 5(3):302-304. http://www.academicjournals.org/AJB

Ogiehor IS and Ikenebomeh MJ (2006). The effects of different packaging materials on the shelf stability of garri. African Journal of Biotechnology 5 (23):2412-2416.

Ogiehor IS, Ikenebomeh MJ and Ekundayo AO (2007). The bioload and aflatoxin content Of market garri from some selected states in southern Nigeria: Public health significance. African Health Sciences 7(4):223-22.

Ogunbanwo ST, Sanni AI and Onilude AA (2004). Effect of Bacteriocinogenic Lactobacillus spp. on the Shelf Life of Fufu, A Traditional Fermented Cassava Product. World Journal of Microbiology and Biotechnology 20:57-63.

Oguntoyinbo FA and Narbad A (2012). Molecular Characterization of Lactic Acid Bacteri and In Situ Amylase Expression during Traditional Fermentation of Cereal Foods. Food Microbiology 31:254-262

Olapade AA and Ogunade OA (2014). Production and Evaluation of Flavours and Crunchy Snacks from Sweet Potato (Ipomea batatas) and Maize Flour. Journal of International Food Resources 21: 203-208

Olatunde OO (2016). Isolation and Molecular Characterization of Probotics from Effluents Generated During Ogi Processing. MSc Dissertation, Federal university of Agriculture, Abeokuta.

Oloyede AR and Afolabi OR (2013). Phenotypic Characterization and Invitro Screening of Lactic Acid Bacteria from Goat Milk for Probiotic Use. Journal of Agricultural Science and Environment 13:50-59

Omemu AM, Oyewole OB and Bankole MO (2007). Significance of Yeasts in the Fermentation of Maize For Ogi Production. Food Microbiology. 246:571-576.

Omemu AM, Bamigbade G, Obadina AO and Obuotor TM (2015). Isolation an Screening of Amylase from Moulds Associated with the Spoilage of some Fermented Cereal Foods. British Microbiology Research Journal 5(4):359-367

Omodamiro RM, Oti E, Egesi CN, Ukpabi UJ, Etudaiye HA and Chijioke U. (2011). Sensory Evaluation of Fufu produced from high $\beta$-carotenoid cassava. In: 35th Annual Conference and AGM of Nigeria Institute of Food Science and Technology. Makurdi, Nigeria

Oranusi S, Braide WM and Oguoma OI (2013). Antifungal Properties of Lactic Acid Bacteria (LAB) Isolated from Ricinus communis, Pentaclethra macrophylla and Yoghurts. Global Advanced Research Journal of Food Science and Technology 2 (1): 1-6.

Oranusi S, Olopade BK, Ajala R and Olorunsola SJ (2014). Microbiological quality of Fermented Cassava (Gari) sold in Ota Ogun State Nigeria. International journal of current microbiology and applied statistics 3(3):888895.

Padonou SW, Nielsen DS, Hounhouigan DJ, Thorsen L, Nago CM and Jakobsen M (2009). The microbiota of Lafun, an African traditional cassava food product. International Journal of Food Microbiology 133:22-30.

Ponce AG, Moreira MR, del Valle CE and Roura SI (2008). Preliminary Characterization of Bacteriocin-like Substances from Lactic Acid Bacteria Isolated from Organic leafy Vegetables. LWT 41:432-441.

Raimbault M (1995). Importance of lactic bacteria in cassava fermentation. In: Cassava food processing. (Eds) T.A,Egbe, A. Branmar, D.Griffon and S.Treche. ORSTEM France. Pp. 256-275.

Rosales-Soto MU, Ross CF, Frank Younce PE, Fellman JK, Mattinson, DS, Kerry H and Powers JR (2012). Physico-Chemical and Sensory Evaluation of Cooked Fermented Protein Fortified Cassava (Manihot Esculenta Crantz) Flour. Advance in Food Technology, Nutrition and Science Open Journal 2(1):9-18. doi: 10.17140/AFTNSOJ-2-126

Sagar KT, Tianyao H, Bussie MD and Mark LF (2009). Impact of processing on Retention and Bioaccessibility of Carotene in Cassava (Manihot esculenta Crantz). J. Agric. Food Chem 57: 1344-1348.

Saranya, S. and Hemashenpagam, N. 2011. Advances in Applied Science Research. 4: 528-534.

Savadogo A, Quattara CAT, Bassole HN and Traore SA (2004). Antimicrobial Activities of Lactic Acid Bacteria Strains Isolated from Burkina Faso Fermented Milk. Parkistan Journal of Nutrition 3(3): 174-179.

Schnurer J and Magnusson J (2005). Antifungal lactic acid bacteria as biopreservatives. Trends in Food Science and Technology. 16: 70-78.

Sjogren J, Magnusson J, Broberg A, Schnurer J and Kenne L (2003). Antifungal 3- hydroxy fatty acids from Lactobacillus plantarum MiLAB 14. Applied Environmental Microbiology 69:7554-7557.

Strom K, Sjorgen J, Broberg A and Schnurer J (2002). Lactobacillus plantarum MiLAB 393 produces the antifungal cyclic dipeptides cyclo(LPhe- L-Pro) and cyclo(L-Phe-trans-4-OH-L-Pro) and 3-phenyllactic acid. Applied Environ. Microbiol. 68:4322-4327. PMID: 122200282

Toyi DM (2014). Molecular Screening of Lactic Acid Bacteria from Fermented Foods and Evaluation of their Inhibitory Activities against Food-Borne pathogens. MSc Dissertation, Federal University of Agriculture, Abeokuta. 
Viljoen CB (2001). The Interaction Between Yeasts and Bacteria in Dairy Environments. International Journal of Food Microbiology 69:37-44.

Wakil SM and Osamwonyi UO (2012). Isolation and screening of antimicrobial producing lactic acid bacteria from fermentating millet gruel. International Research Journal of Microbiology (IRJM) 3(2):072-079, (ISSN: 2141-5463)

World Health Organization (2002). Quantifying Selected Major Risks to Health. The World Health Report :Reducing Risks: Promoting Healthy Life, Geneva, 2002, pp. 47-97. 